\title{
kolos $1 . \quad$ SYSTEMATIZATION AND DEVELOPMENT OF THE PROVISIONS FOR STATEMENT OF LEAN SYNCHRONIZATION ACCOUNTING OF CASH FLOW FROM OPERATING ACTIVITIES OF INDUSTRIAL ENTERPRISES
}

Об'єктом дослідження є складники ощадливого обліку грошових коштів від операційної діяльності у їх взаємодії з урахуванням спрямованості на мінімізащію втрат в системі ощадливого управління. За організаиійним аспектом аргументовано переглянути склад працівників облікової служби шляхом узгодження взаємодї з персоналом в межах посадових обов'язків і рівня професійної компетентності. За методичним аспектом обгрунтовано застосування методів ощадливого виробництва (Standard Operating Procedure, Value Stream Mapping, Poka-Yoke, 5 S, Just-in-Time, Visual Management, Single Minute Exchange of Dies) в поєднанні з методами стратегічного управлінського обліку ( $A B C, X Y Z, R F M, F M R$, VEN, QRS) при дотриманні методів фінансового обліку. За технологічним аспектом доведено доцільність розроблення внутрішніх стандартів підприємства з постановки ощадливого обліку синхронізації грошового потоку від операційної діяльності промислового підприємства за потоком створення цінності.

За результатами застосування методів системного і критичного аналізу обтрунтовано елементи базису ощадливого обліку підприємства: мета обліку і користувачі інформації; приниипи, методи, об'єкти, вимірники та обов'язковість ведення обліку; часовий горизонт; джерела інформації. За результатами виконання наукового інформаційного пошуку і логічного узагальнення встановлено основні орієнтири ощадливого обліку підприємства. Виконано порівняння ощадливого обліку за елементами базису з фінансовим обліком, управлінським обліком та стратегічним управлінським обліком.

Доведено важливість ощадливого обліку в управлінні сучасним промисловим підприємством з позиціі посилення ролі інформащії і ї цінності для обгрунтування і ухвалення кращих управлінських рішень з фокусуванням на задоволенні вимог замовників і врахуванням інтересу постачальників.

Удосконалено методичний підхід до виявлення і узагальнення складу чинників впливу на синхронізацію грошового потоку від операційної діяльності промислового підприємства, а також встановлення причиннонаслідкових взаємозв'язків між ними шляхом використання діаграми Ісікави. За результатами використання графічного методу встановлено ключові чинники впливу: обсяг, якість, цінність та час.

Ключові слова: ощадливий облік, синхронізація грошового потоку, методи ощадливого виробництва, промислове підприємство.

\section{Introduction}

In modern conditions, the synchronization of the cash flow in time as an important component of the financial policy of each enterprise becomes particularly important. The balance of the volume of cash inflows and cash outflows, in particular from the operating activities of an industrial enterprise [1]:

- allows to maintain an appropriate level of current

solvency and financial strength;

- ensures the rational use of temporarily free cash;

- contributes to the early identification of a crisis or

an artificial creation of a crisis.

At the same time, there is a need to establish a minimum sufficient balance of cash. The urgency of the problem is strengthened by setting rational accounting with the focus on the formation of quality information support for settlements with personnel, suppliers, buyers, and government institutions. This involves the introduction of accounting for the synchronization of cash flow from operations on the principles of lean manufacturing, which creates the conditions for successful operation and sustainable economic development.

\section{The object of research and its technological audit}

The object of research is the components of lean accounting of cash from operating activities in their interaction, taking into account the focus on minimizing waste in the system of lean management.

It should be noted that it is advisable to introduce lean accounting, in which the role of information and its value is strengthened in order to justify and make better management decisions, focusing on satisfying customer requirements and taking into account suppliers' interests [2]. On the organizational aspect, it is advisable to review the composition of the accounting service employees and their role in managing the enterprise on the basis of frugality. At the same time, to coordinate interaction with other 
personnel within the limits of official duties and the level of professional competence. On the methodological aspect, it is appropriate to determine the correct methods of lean accounting, financial accounting and strategic management accounting. To provide opportunities for the integrated use of effective methods for activating cost-effective transformations with the focus on reducing waste, achieving and maintaining the expected result at the planned level. On the technological side, it is appropriate to develop a system of internal standards that regulate the keeping of lean accounting, in particular, the synchronization of cash flow from the operating activities of an industrial enterprise through the value stream.

It should be noted that the formation of information on the status and changes in cash flow from operating activities has a significant impact on the financial balance of the enterprise. It is important and difficult to justify the factors influencing the synchronization of cash receipts and expenses from operating activities. At the same time, it is advisable to identify the key factors of cash flow synchronization, to find out their subordination and the direction of the action with the aim of making weighted economic decisions. Thus, the choice of lean manufacturing methods is the key to the rational organization of cash flow accounting in the system of lean management of an industrial enterprise.

\section{The aim and objectives of research}

The aim of research is systematization and development of the theoretical and methodological provisions for recording the synchronization of funds from the operating activities of an industrial enterprise to strengthen the computational discipline on a continuous basis.

Achieving this aim has made it necessary to solve the following scientific problems:

1. Based on the results of studying published works of scientists and practitioners, establish a basis for lean accounting with justification of the importance in the management of a modern industrial enterprise.

2. Substantiate the main methodological provisions of the accounting for the synchronization of cash flow from the operating activities of an industrial enterprise, based on strategic and integrated approaches in the context of lean manufacturing.

\section{Research of existing solutions of the problem}

A critical analysis of published scientific results on the problems of the research allowed them to be systematized according to the thematic focus in the following areas:

1. Justification of the need for evolutionary changes in the organization of accounting. The author of the paper [3] presents the results on the comparative characteristics of financial accounting and management accounting. The importance of their integrated approval is proved, which helps management to justify and make correct and timely decisions. At the same time, the importance of continuous updating of knowledge and continuous learning was noted. However, the further direction of the evolution of accounting is not determined with the orientation toward applying a strategic approach to enterprise management.
Correct is the position of the authors [4] on the need to take into account the internal and external factors of the enterprise to ensure a reliable representation of interrelated data on performance and development for the long term. This is one of the important tasks, it is decided by strategic management accounting. In work [5] its interrelation with strategy and value in enterprise management as system of the balanced estimation and the control over results of activity is underlined. Also the main differences from traditional management accounting and systematized methods of strategic management accounting are outlined. But there are no practices on the importance of accounting as a function of enterprise management in the context of lean manufacturing.

In modern conditions, the dominant approach in the management of an industrial enterprise is the concept of lean manufacturing, on the basis of which the accounting system should be formed [6,7]. The system of lean accounting is aimed at the generation of useful and timely information (a logically coordinated combination of financial and non-financial data) about costs and losses, the results of economic changes and the continuous improvement of their level. The paper [7] presents a comparison and interrelation of managerial accounting, strategic cost management and lean accounting.

There is no single position on the barriers to the implementation of lean accounting of industrial enterprises. At the initial stage of the introduction of lean accounting, it is advisable to consider the obstacles that are caused by cultural, technical, organizational and economic factors [8]. But it is possible to agree with the conclusion [9] that the primary reason for the lack of lean accounting in the practice of business entities is communicative barriers. This is manifested through partial understanding/misunderstanding of the importance of lean transformations and the lean accounting of personnel, in particular by the accounting service specialists.

A weighted statement of the scholarly work [10] on the implementation of lean accounting should be accompanied by changes in all components of the accounting organization at the enterprise:

- methodical way of changing the methods of accounting for various objects;

- technological through the review of ways of accumulating information and changing approaches to the organization of control;

- organizational way of changing approaches to the organization of work of employees and viewing their duties. At the same time, in practice of lean accounting it is expedient to take into account the following main limitations [11]: - lack of initiation and support by the management of the introduction of lean accounting, training and development of personnel for the development, implementation and operation of lean accounting;

- reluctance to change traditional culture and behavior, traditional approaches to enterprise management from focusing on indicators of financial and tax reporting in an orientation to indicators of consumer satisfaction; - lack of specialists with sufficient level of professional competence in the field of lean manufacturing and lean reforms;

- inadequate management and accounting staff of theoretical knowledge and experience in using modern methods, techniques, methods and procedures of lean accounting, their advantages and features. 
2. Establishing the importance of cash flow for an industrial enterprise. Correct is the statement about the paramount importance of cash flow for sustainable economic development of the enterprise [12]. In the scientific paper [13], the cash flow is proposed to be used as a criterion for justifying alternatives for making rational economic/management decisions. At the same time, sufficient cash flow from operating activities indicates the effectiveness of enterprise management.

At the same time, insufficient attention is paid to the balancing of cash flow from operating activities in the lean management of an industrial enterprise, and the methods of lean production in the context of consistency in the volume of receipt and expenditure of money have not yet been properly justified. This determines the prospects for this problem and the need for this research.

\section{Methods of research}

During the research, the following methods were used to solve the tasks:

- system and critical analysis, scientific information retrieval, logical generalization - for setting the basic guidelines for lean accounting of an industrial enterprise with the allocation of a basis;

- structural and logical analysis, groupings, graphical method (Ishikawa diagram) - to determine the possible factors influencing the synchronization of cash flow by identifying key and establishing significant cause-effect relationships and the consequences of interference.

At the same time, general scientific methods of scientific research are used-synthesis, induction, deduction, monographic method.

\section{Research results}

Accounting in the lean manufacturing concept is recognized as the main function of managing a modern enterprise to provide reliable and sufficient information to interested parties [2, 12]. It is worth noting that this raises the need for fundamental changes in the traditional methods of accounting, primarily management, with a focus on a new type of production, the calculation of indicators, assessing the performance of the enterprise and the results of economic changes.

The search for ways of correct setting of lean accounting is carried out since 2005 by participants of special summits «Lean Accounting Summit» [14]. Within the sessions, scientists, consultants and practitioners review and discuss the results and best practices of introducing principles of lean production into an accounting system with an emphasis on the value of information. In 2017, the «Lean Management \& Accounting Summit» is devoted to topical issues of the influence of personnel with lean thinking on the creation of lean enterprise through the integration of lean management and lean accounting. In 2018, «Lean Accounting \& Management Summit» shifts the focus on the priority of accounting in the management of a modern industrial enterprise. This confirms the importance of lean accounting in the management of a modern industrial enterprise for the purpose of lean production.

Based on the results of processing normative acts and scientific publications, the basis of lean accounting is sys- tematized. For a better understanding, the relationship and differences in relation to other types of accounting are generalized (Table 1).

As part of research, lean accounting is considered as information support for justifying the best options for daily decisions, focusing on ensuring the value of accounting information to the interested person (the end user). To strengthen the effectiveness of lean accounting methods in the context of the implementation of the lean manufacturing concept, it is appropriate to apply methods of strategic management accounting with an orientation of the result [2]:

- in the short term (15-60 days);

- in the medium term (6 months).

At the same time, compliance with the methods of financial accounting is aimed at reducing losses and taking into account legal norms of the legislation.

It is advisable to consider the organization of lean accounting from the position of the interested user. The setting of lean accounting is appropriate in view of the requirements of the SMA IMA «Accounting for the Lean Enterprise: Major Changes to the Accounting Paradigm», subject to the five principles of lean manufacturing [2, 17]:

1) Value;

2) Value Stream;

3) Flow and Pull;

4) Empowerment;

5) Perfection.

It is proposed to consider the value as a result of the activity of specialists of the accounting service, is embodied in the enterprise's reporting package. The value of reporting for the owner, who is considered to be the main user, is manifested through the following characteristics: - quantity - is associated with types and forms of reporting, the level of key indicators;

- quality - reliability and adequacy of data is ensured by fundamental qualitative characteristics (relevance, faithful representation) and enhancing qualitative characteristics (comparability, verifiability, timeliness, understandability), a list of key indicators;

- term - the date of submission of financial and management information is clearly established by the internal standards of the enterprise.

Similarly, it is expedient to determine the interested user (within the accounting service and establish information links with all departments and implementers along the value stream) and the value created for it.

Within the framework of the second principle, it is appropriate to implement lean accounting behind the value stream, it is the main object of accounting. The most difficult and important problem is the allocation of value streams within a single industrial enterprise. This is due, above all, to focusing on increasing the value from the position of the customer information; the focus of attention of top management on identifying unproductive expenditures and excluding actions/operations that are created. To overcome this problem, it is advisable to build value-stream maps (current-state map, future-state map, ideal-state map [18]). Their presence facilitates the division of operations into groups (value-added, required non-value-added, non-value-added). This helps to establish unproductive costs and processes/hidden losses, as well as to justify a plan for improving and improving accounting procedures and procedures. 
Comparative characteristics of lean accounting with financial accounting, management accounting and strategic management accounting

\begin{tabular}{|c|c|c|c|c|}
\hline $\begin{array}{l}\text { Base } \\
\text { element }\end{array}$ & Lean accounting & Financial accounting & Management accounting & $\begin{array}{l}\text { Strategic management } \\
\text { accounting }\end{array}$ \\
\hline $\begin{array}{l}\text { Purpose of } \\
\text { accounting }\end{array}$ & $\begin{array}{l}\text { Formation of information on lean } \\
\text { transformations with a focus on } \\
\text { changing performance indicators } \\
\text { in the current and medium term } \\
\text { to justify weighted lean management } \\
\text { decisions }\end{array}$ & $\begin{array}{l}\text { Formation of complete, truthful } \\
\text { and impartial information on } \\
\text { the financial condition, perfor- } \\
\text { mance and cash flows of the } \\
\text { enterprise for decision-making }\end{array}$ & $\begin{array}{l}\text { Formation of information on ac- } \\
\text { tivities for planning, forecasting, } \\
\text { management, analysis, control } \\
\text { and justification of manage- } \\
\text { ment decisions with a focus on } \\
\text { internal business processes }\end{array}$ & $\begin{array}{l}\text { Formation of information on the } \\
\text { functioning of the enterprise with } \\
\text { an orientation to the rationale for } \\
\text { long-term management decisions } \\
\text { with a focus on the external busi- } \\
\text { ness environment }\end{array}$ \\
\hline $\begin{array}{l}\text { Information } \\
\text { users }\end{array}$ & $\begin{array}{l}\text { Interested parties (owners, manage- } \\
\text { ment, personnel, customers, sup- } \\
\text { pliers) in obtaining value }\end{array}$ & $\begin{array}{l}\text { A wide range of external and } \\
\text { internal users }\end{array}$ & $\begin{array}{l}\text { Limited number of internal } \\
\text { users (management and manage- } \\
\text { ment personnel) in accordance } \\
\text { with the level of professional } \\
\text { competence }\end{array}$ & $\begin{array}{l}\text { Limited number of internal users } \\
\text { (management and management } \\
\text { personnel) in accordance with the } \\
\text { level of professional competence }\end{array}$ \\
\hline $\begin{array}{l}\text { Accounting } \\
\text { principles }\end{array}$ & $\begin{array}{l}\text { Lean production (value, value } \\
\text { stream, the principle of continuity } \\
\text { of flow, the principle of continuous } \\
\text { improvement of business processes, } \\
\text { the principle of operational control); } \\
\text { financial accounting }\end{array}$ & $\begin{array}{l}\text { Generally accepted accoun- } \\
\text { ting principles (full coverage, } \\
\text { consistency, continuity, accrual, } \\
\text { prevalence of essence over } \\
\text { form, single monetary meter, } \\
\text { autonomy, periodicity, historical } \\
\text { cost, caution) }\end{array}$ & $\begin{array}{l}\text { General scientific (purposeful- } \\
\text { ness, systematic, validity) of } \\
\text { financial accounting; specific } \\
\text { (efficiency, systematic, realistic, } \\
\text { rational, accountable) }\end{array}$ & $\begin{array}{l}\text { General scientific; financial } \\
\text { accounting; specific (efficiency, } \\
\text { systematic, balanced, integrated, } \\
\text { realistic, rational, optimistic, ac- } \\
\text { countable) }\end{array}$ \\
\hline $\begin{array}{l}\text { Accounting } \\
\text { methods }\end{array}$ & $\begin{array}{l}\text { - methods of lean manufacturing; } \\
\text { - methods of financial accounting; } \\
\text { - methods of statistics; } \\
\text { - methods of economic analysis; } \\
\text { - mathematical methods; } \\
\text { - methods of strategic and opera- } \\
\text { tional planning; } \\
\text { - logistic methods }\end{array}$ & $\begin{array}{l}\text { - documentation and inventory; } \\
\text { - estimating and calculating; } \\
\text { - accounting accounts and } \\
\text { double entry; } \\
\text { - balance sheet and reporting }\end{array}$ & $\begin{array}{l}\text { - methods of financial accounting; } \\
\text { - statistical methods (indices, } \\
\text { groupings, control accounts); } \\
\text { - methods of economic analysis } \\
\text { (factor analysis, horizontal } \\
\text { analysis, vertical analysis, ratio } \\
\text { analysis, trend analysis); } \\
\text { - mathematical methods (corre- } \\
\text { lation, linear programming, } \\
\text { modeling); } \\
\text { - methods of strategic and } \\
\text { operational planning (planning, } \\
\text { budgeting, rationing, scenario } \\
\text { analysis) }\end{array}$ & $\begin{array}{l}\text { - methods of financial accounting; } \\
\text { - methods of statistics; } \\
\text { - methods of economic analysis } \\
\text { (SWOT, SPACE, PEST, PIMS, ABC); } \\
\text { - mathematical methods; } \\
\text { - methods of strategic and ope- } \\
\text { rational planning (activity-based } \\
\text { costing, lifecycle costing, target } \\
\text { costing, JIT-costing, Balanced } \\
\text { Scorecard, benchmarking); } \\
\text { - logistic methods (ABC, XYZ, } \\
\text { RFM, FMR, VEN, QRS, SPACE, } \\
\text { PIMS) }\end{array}$ \\
\hline $\begin{array}{l}\text { Accounting } \\
\text { objects }\end{array}$ & The value stream & $\begin{array}{l}\text { Assets; liabilities; equity; in- } \\
\text { come; costs; financial results }\end{array}$ & $\begin{array}{l}\text { Production resources; business } \\
\text { processes and their results; cen- } \\
\text { ters of financial responsibility }\end{array}$ & $\begin{array}{l}\text { Centers of financial responsibi- } \\
\text { lity; activities; business processes; } \\
\text { value chain; future performance }\end{array}$ \\
\hline $\begin{array}{l}\text { Metering } \\
\text { devices }\end{array}$ & $\begin{array}{l}\text { Corresponding monetary, natural } \\
\text { and labor meters, quantitative and } \\
\text { qualitative indicators for the forma- } \\
\text { tion of operational and strategic } \\
\text { information }\end{array}$ & Monetary, natural, labor & $\begin{array}{l}\text { Corresponding monetary and } \\
\text { natural meters for the formation } \\
\text { of operational information }\end{array}$ & $\begin{array}{l}\text { Corresponding monetary and } \\
\text { natural gauges, quantitative and } \\
\text { qualitative gauges for formation } \\
\text { of strategic information }\end{array}$ \\
\hline $\begin{array}{l}\text { Mandatory } \\
\text { accounting }\end{array}$ & $\begin{array}{l}\text { Depends on management/owners } \\
\text { decision }\end{array}$ & $\begin{array}{l}\text { It is regulated by the current } \\
\text { legislation, in particular in } \\
\text { Ukraine }[15,16]\end{array}$ & $\begin{array}{l}\text { Depends on management } \\
\text { decision }\end{array}$ & Depends on management decision \\
\hline $\begin{array}{l}\text { Time } \\
\text { horizon }\end{array}$ & $\begin{array}{l}\text { Along with the actual data, the } \\
\text { assessment for the medium term } \\
\text { (forecast) }\end{array}$ & $\begin{array}{l}\text { Fixation of economic facts in } \\
\text { accounting for the period of } \\
\text { operations or immediately } \\
\text { after their completion }\end{array}$ & $\begin{array}{l}\text { Along with the actual data, } \\
\text { the assessment for the future } \\
\text { (forecast) }\end{array}$ & $\begin{array}{l}\text { Along with the actual data, long- } \\
\text { term assessment (forecast) }\end{array}$ \\
\hline $\begin{array}{l}\text { Information } \\
\text { sources }\end{array}$ & $\begin{array}{l}\text { The list of documents and their } \\
\text { forms are determined by the } \\
\text { enterprise taking into account lean } \\
\text { methods (Visual Management, Value } \\
\text { Stream Mapping, Standard Opera- } \\
\text { ting Procedure) }\end{array}$ & $\begin{array}{l}\text { The list of documents and their } \\
\text { forms are officially approved }\end{array}$ & $\begin{array}{l}\text { The list of documents and their } \\
\text { forms are determined by the } \\
\text { enterprise, proceeding from the } \\
\text { list of management decisions }\end{array}$ & $\begin{array}{l}\text { The list of documents and their } \\
\text { forms are determined by the } \\
\text { enterprise, proceeding from the } \\
\text { list of management decisions }\end{array}$ \\
\hline
\end{tabular}

Note: compiled by the author taking into account [3, 5, 7] 
Observance of the third principle allows to concentrate efforts on reduction of time and acceleration of satisfaction of the request of the consumer within the established streams of value stream.

To ensure operational control, it becomes necessary to justify key performance indicators in three levels [2]:

1) indicators of the workplace efficiency;

2) efficiency indicators of the value stream;

3) performance indicators of the enterprise as a whole.

Compliance with the fifth principle contributes to the continuous expansion of professional competence and the development of professional skills of accounting professionals, and also provides motivation for continuous self-improvement and improvement of value creation activities. It should be noted that the introduction of the lean manufacturing concept at an industrial enterprise necessarily involves justifying unique approaches and adapting existing methods, techniques, methods and procedures, in particular the accounting process. This involves taking into account the mentality and features of the functioning of the business, as well as the continuous training of all personnel in the theory of lean production and familiarization with the latest practical achievements. The only indispensable is the orientation of management - continuous improvement and reduction of waste with subsequent minimization to elimination in the value stream, the adoption of Lean Thinking and Lean Culture.

It is important to take into account the cash flow as a component of the value stream, which is consistent with the material and information flows. The rational generation of cash allows:

1) ensure the rhythm and timeliness of payments;

2) lean use of temporarily free funds;

3) reduce dependence on raising funds as a result of financial and investment activities.

The task of the company's management is development of measures to increase the expected funds, taking into account the direction of the impact of various factors.

Based on the results of the use of the graphical method of visualization of cause-effect relationships (a methodical approach is described in [19]), systematization of factors of influence on the synchronization of cash flow from operating activities was carried out, with the identification of key:

1) volume;

2) quality;

3) value;

4) time.

Ishikawa diagram is constructed (Fig. 1), where neither subordination nor the relationship between the most important components of the impact is shown.

Synchronization and balancing of the total cash flow from operating activities is achieved by generating cash receipts and a clear routing of cash costs. This ensures the use of the lean method of Standard Operating Procedure. The development and approval within the enterprise of internal standards of lean accounting, in particular: accounting policy (set forth in paper [20]), the regulation of the value stream map, the methodology for the formation of individual budgets are proposed. Thus, the Rules of the Value Stream Map Regulation is a standard of enterprises, which is defined in a graphic form a dia- gram of all stages of the cash flow movement with the coordination of material and information flows by types of cards of value streams [18]:

$$
\begin{aligned}
& \text { - current-state map; } \\
& \text { - future-state map; } \\
& \text { - ideal-state map. }
\end{aligned}
$$

The methods for the formation of individual budgets include the development of such standards of the enterprise:

1. The budget of cash flow behind the value stream, where the description of the budget generation model for medium-term monitoring is fixed.

2. Schedule of cash receipts and a schedule of expenses from operating activities, within the framework of which the classification of existing accounts receivable and payable for the current monitoring and evaluation of the ratio.

3. Payment calendar, where an ordered schedule of cash inflows and cash outflows from operating activities is established. The main purpose of the payment calendar is monitoring the cash flow budget on a daily basis. This is done by tracking the receipt of funds in the planned amount in anticipation of the timeframe, followed by the prioritization of payments.

The time horizon for the synchronization of cash flow from the operating activities of an industrial enterprise should include from 6 to 13 weeks. At the same time, it is advisable to ensure the planning of cash receipts and expenditures on a daily basis with an orientation toward minimizing cash gaps. Corrective measures should be implemented with a focus on stabilizing payment discipline and constant monitoring of compliance with internal standards.

To ensure the establishment of lean accounting of the synchronization of funds from operating activities, it is expedient to apply lean manufacturing methods:

- Standard Operating Procedure for developing and adjusting/improving the internal standards of an industrial enterprise in terms of organizational, methodological and technological aspects of setting lean accounting for the synchronization of cash flow from operating activities;

- Poka-Yoke for rational selection of accounting service personnel and organization of the orderly activity of individual specialists with a focus on the continuous improvement of their professional competence;

- $5 \mathrm{~S}$ for systematization and allocation of groups of receivables and payables in different priority areas, while using strategic management accounting methods (ABC, XYZ, RFM, FMR, VEN, QRS), and streamlining documentary accounting;

- Just-in-Time for timely documenting the accounting of cash inflows and cash outflows from the operating activities of an industrial enterprise;

- Visual Management to determine the cash cycle of the enterprise, ensure the adequacy and intensity of the formation of cash, identified cash gaps and violations of the consistency of the priority order of payments;

- Single Minute Exchange of Dies for the consistency of all technical systems on local and network accounting systems, including settlements with banking institutions. 


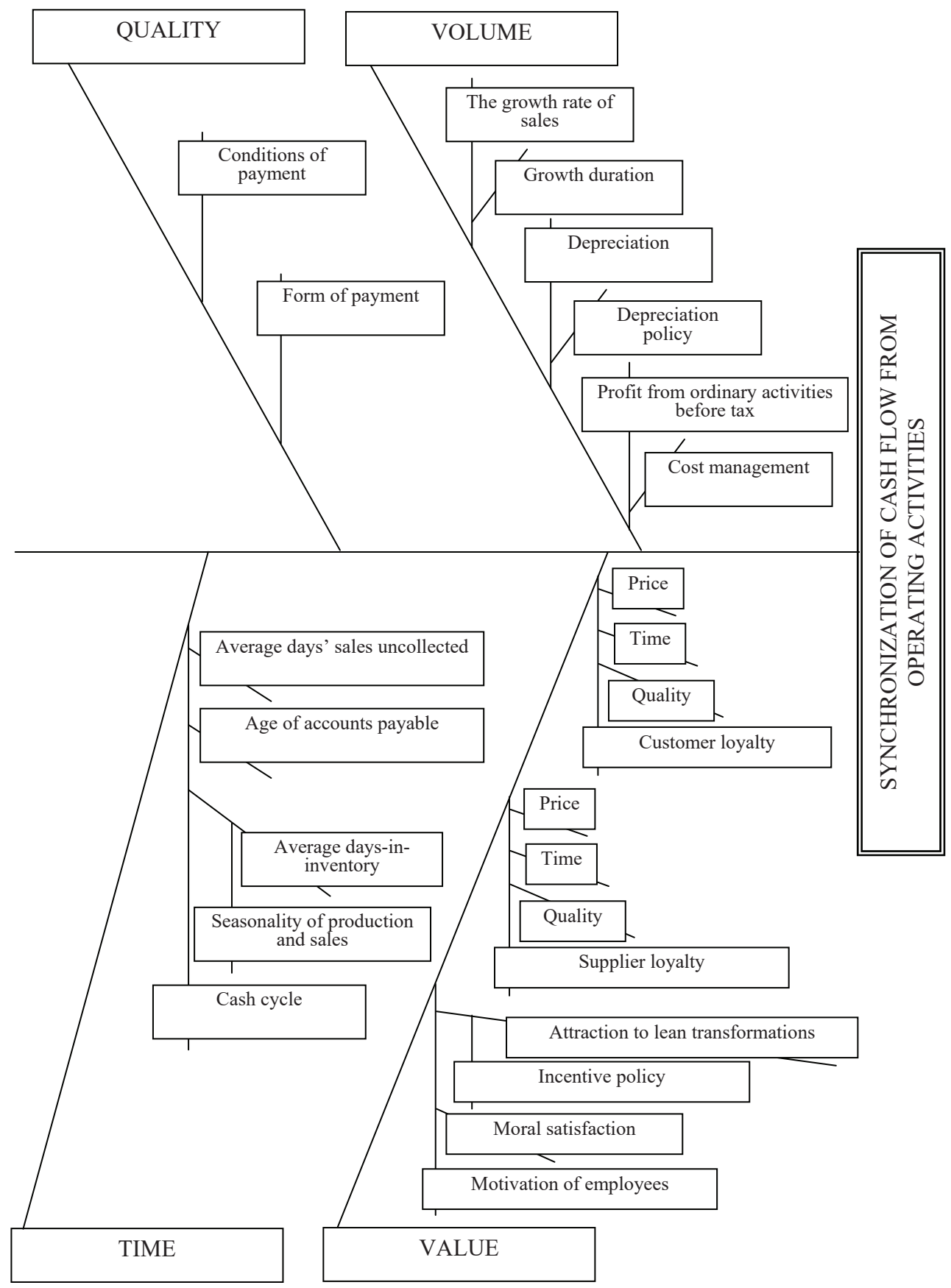

Fig. 1. The key factors of the synchronization of cash flow from the operation of an industrial enterprise

\section{SWOT analysis of research results}

Strengths. The strength of research is the rationale for the basis of lean accounting in comparison with financial accounting, management accounting and strategic management accounting. The further development of a combination of methods of strategic management accounting and lean production to synchronize the accounting of cash from the operating activities of an industrial enterprise provides a targeted generation of cash. This is for the purpose of making reasonably balanced lean management decisions with a focus on the constant maintenance of an acceptable level of solvency and liquidity of the industrial one.

Weaknesses. The weak side is the choice of elements of the basis of lean accounting and the identification of key factors of influence on the synchronization of cash flow from the operating activities of an industrial enterprise. The obtained results are subjective in nature and may not be complete, therefore, it is necessary to carry out a scientific search in this area of research carefully.

Opportunities. The opportunities for further research are experimental confirmation by testing the proposed methodological guidelines for synchronizing cash flow from the operating activities of an industrial enterprise, in particular the food sector of the economy.

Threats. Threats to further research are the maintenance of the benefit/loss ratio in the practical implementation by industrial enterprises of lean accounting of cash flow synchronization from operating activities, as well as the level of professional competence of management and executors. 


\section{Conclusions}

1. The theoretical basis of the lean accounting of an enterprise with the establishment of nine elements is theoretically justified: the purpose of accounting and information users, principles, methods, objects, meters and compulsory accounting, time horizon and sources of information. The lean accounting is characterized in comparison with financial accounting, management accounting and strategic management accounting according to the selected benchmarks.

The importance of lean accounting in the management of a modern industrial enterprise is proved. The relevance of setting lean accounting with respect for the principles of lean production is justified. The value stream as an accounting object in the system of lean management of an industrial enterprise is argued, and the cash flow as one of its components.

The synchronization of cash flow from the operation of an industrial enterprise is affected by a significant number of factors. The necessity of their systematization using the Ishikawa diagram is proved, which allows to identify the subordination of the influence factors with the identification among them of the key ones:

1) volume;

2) quality;

3) value;

4) time.

2. The use of lean manufacturing methods (Standard Operating Procedure, Value Stream Mapping, Poka-Yoke, 5 S, Just-in-Time, Visual Management, Single Exchange Exchange) is further developed in combination with the methods of strategic management accounting (ABC, XYZ, RFM, FMR, VEN, QRS) to enhance the synchronization of cash flow from the operation of an industrial enterprise.

The expediency of development of internal standards of the enterprise on setting lean accounting of cash flow synchronization is proved:

- accounting policy;

- rules of the value stream map;

- methodology for the formation of a cash flow budget for the value stream;

- methodology for the formation of a schedule of cash receipts and a schedule of expenses from operating activities;

- method of forming a payment calendar.

\section{References}

1. Ryan B. Strategic Accounting for Management. Cengage Learning EMEA, 1995. $384 \mathrm{p}$.

2. Maskell B. H., Baggaley B., Grasso L. Practical Lean Accounting: A Proven System for Measuring and Managing the Lean Enterprise. Productivity Press, 2011. 475 p.

3. Zubac I. Financial accountant versus managerial accountant in the hotel business system // Turizam. 2012. Vol. 16, Issue 1. P. 1-7. doi: http://doi.org/10.5937/turizam1201001z
4. Almasan A. C., Grosu C. A strategic approach of management accounting // Annals of Faculty of Economics. 2009. Vol. 3, Issue 1. P. 736-741. URL: https://core.ac.uk/download/pdf/ 6304212.pdf

5. Juras A. Strategic Management Accounting - What Is the Current State of the Concept? // Economy Transdisciplinarity Cognition. 2014. Vol. 17, Issue 2. P. 76-83. URL: http:// www.ugb.ro/etc/etc2014no2/13_Juras_A.pdf

6. Plakhtii T. F. Rozvytok orhanizatsii obliku na osnovi kontseptsii oshchadlyvoho vyrobnytstva // Visnyk ZhDTU. 2017. Issue 3 (81). P. 25-30.

7. Interactions, convergences and interrelationships between Lean Accounting and Strategic Cost Management: a study in the Lean Production context / Collatto D. C. et. al. // Gestao \& Producao. 2016. Vol. 23, Issue 4. P. 815-827. doi: http://doi.org/ 10.1590/0104-530x1279-15

8. Darabi R., Moradi R., Toomari U. Barriers to Implementation of Lean Accounting in Manufacturing Companies // International Journal of Business and Commerce. 2012. Vol. 1, Issue 9. P. 38-51. URL: https://www.ijbcnet.com/1-9/IJBC-12-1804.pdf

9. Koriahin M. V., Chik M. Yu. Problemy vprovadzhennia Lean obliku na pidpryiemstvakh: Proceedings // Finansovo-ekonomichnyi rozvytok Ukrainy v umovakh transformatsinykh peretvoren. Lviv: LKA, 2015. P. 118-120.

10. Liakhovych H. I. Kontseptsiia oshchadlyvoho vyrobnytstva: osnovni polozhennia ta vplyv na orhanizatsiiu obliku // Problemy teorii ta metodolohii bukhhalterskoho obliku, kontroliu i analizu. 2015. Vol. 3, Issue 33. P. 139-146.

11. Lean accounting: best practices for sustainable integration ed. by Stenzel J. John Wiley \& Sons, Inc., 2007. 344 p.

12. Fiume O. Lean Accounting and Finance. Cash flow tells the tale // Target. 2002. Vol. 18, Issue 4. P. 6-14. URL: http:// www.ame.org/sites/default/files/target articles/02-18-4-Lean Accounting.pdf

13. Konkurentospromozhnist pidpryiemstva: otsinka rivnia ta napriamy pidvyshchennia: monograph / ed. by Yankovyi O. H. Odessa: Atlant, 2013. 470 p.

14. Lean Accounting Summit. URL: http://leanaccountingsummit.com/

15. Pro bukhhalterskyi oblik ta finansovu zvitnist v Ukraini: Zakon Ukrainy No. 996-XIV. 16.07.1999. URL: http://zakon4.rada. gov.ua/laws/show/996-14

16. Pro zatverdzhennia Natsionalnoho polozhennia (standartu) bukhhalterskoho obliku 1 《Zahalni vymohy do finansovoi zvitnosti»: Nakaz Ministerstva finansiv Ukrainy No. 73. 07.02.2013. URL http://zakon0.rada.gov.ua/laws/show/z0336-13

17. IMA The Association of Accountants and Financial Professionals in Bisness. URL: https://www.imanet.org/-/media/f56cba3786e148f486a61df52b0c03ee.ashx?as $=1 \& \mathrm{mh}=200 \& \mathrm{mw}=200$

18. Lean Lexicon a graphical glossary for Lean Thinkers. Version 4.0 / ed. by Marchwinski C., Shook J., Schroeder A. Compiled by the Lean Enterprise Institute, 2008. 136 p.

19. Ishikawa K. What is Total Quality Control?: The Japanese Way. Prentice Hall, 1985. 215 p.

20. Kolos I. V. Osoblyvosti oblikovoi polityky pidpryiemstva v konteksti oshchadlyvosti // Ekonomichni nauky. Seriia «Oblik i finansy». Zbirnyk naukovykh prats. Lutskyi natsionalnyi universytet. 2015. Issue 12 (45). Part. 1. P. 149-157.

Kolos Iryna, PhD, Associate Professor, Certified Accounting Practitioner, Department of Accounting and Auditing, National University of Food Technologies, Kyiv, Ukraine, e-mail: irynakolos2016@gmail.com, kolos_i@meta.ua, ORCID: http://orcid.org/0000-0001-7134-1441 